\title{
SENSITIVITY ANALYSIS IN INVESTMENT PROJECT OF BIOGAS PLANT
}

\author{
KALINICHENKO, A. $.^{{ }^{*}}-$ HAVRYSH, $\mathrm{V}^{2}-$ PEREBYYNIS, V. ${ }^{3}$ \\ ${ }^{1}$ Opole University \\ ul. Dmowskiego 7-9, Opole 45-365, Poland \\ ${ }^{2}$ Mykolayiv National Agrarian University \\ 9 Georgiy Gongadze Str., Mykolayiv 54020, Ukraine \\ phone: +38-0-50-184-26-88 \\ ${ }^{3}$ Poltava University of Economics and Trade \\ 3 Koval Str., Poltava 36014, Ukraine \\ phone: +380958145938 \\ *Corresponding author \\ e-mail: akalinichenko@uni.opole.pl; phone: +48-7-87-321-587
}

(Received $31^{\text {st }}$ Jan 2017; accepted $20^{\text {th }}$ Jul 2017)

\begin{abstract}
The article shows the practical value of biogas as the second generation biofuel. All the projects dealing with biogas are subjected to external risks, such as the change of market condition, customer needs, governmental regulation, etc. In conditions of uncertainty it is necessary for administration to concentrate on decision-making. Fluctuations of sales volume, energy resources and raw material prices, etc. should be taken into account. Sensitivity analysis can predict the result of negative external phenomena. We developed the economic-mathematical model for the analysis of biogas complexes sensitivity. The profitability index as a criterion for the effectiveness of investment projects is a special feature in this model. The calculations show that biogas optimal distribution provides much larger gross income. We also suggested the methodology for sensitivity analysis implementation in investment projects for biogas complex creation. According to our calculations, the most stable project has utilization both biomethane (as motor fuel) and carbon dioxide. We demonstrate that the use of the profitability index as a criterion for an investment project gives higher critical values of input external factors, that endows assured profitability of an investment project.
\end{abstract}

Keywords: biomethane, profitability index, net present value, critical point, carbon dioxide, motor fuel

\section{Introduction}

Exhaustible fossil energy resources and ecological problems are among the major threats of modern civilization. Therefore, nowadays there are acute problems such as efficient use of traditional energy resources, implementation of energy-saving technologies, reduction of energy production intensity and the use of alternative energy resources including renewable ones (Brower et el., 2006; Stern, 2007).

Science has developed and used the civilizational approach to the understanding of the history of mankind. The transition from one stage of civilization maturity to another takes place due to deep qualitative changes of productive forces of the society and growth of labor productivity. These changes are impossible without an increase in the use of energy resources.

In the researchers' opinion, the power engineering is developed as follows (Fig. 1.):

- reducing energy intensity of production;

- increased use of fossil energy resources, which reserves exceed the reserves of petroleum; 
- the use of renewable energy sources;

- the use of energy resources has to comply with envirinmental standards.

Since the end of the twentieth century, there has been a tendency to reduce the use of hydrocarbon fossil fuels due to intensive utilization of renewable energy, including biofuels. Therefore, there has been a spiral trend in the use of energy at a higher technological level. In ancient times, biofuels were used in the primary form (wood or agricultural waste), but nowadays they are mainly utilized in a more convenient, processed form such as briquettes, liquid or gaseous biofuels.

The first generation biofuels are produced from crops. As a result, it decreases food producing. More than one billion people are starving regularly worldwide. In 2008 this fact forced the United Nations to appeal to suspend production of biofuels from crops which can be used for food (LSB, 2013). Thus, production of the second-generation biofuels (from non-food plant resources) is a promising direction. It will not increase the deficit of food crops (Patyka et al., 2016). Animal and crop waste, municipal and industrial waste water, solid waste landfill are substrates for biogas production. Such gaseous biofuel can be used as a substitute for natural gas and motor fuels. Therefore, biogas production is an encouraging step forward.

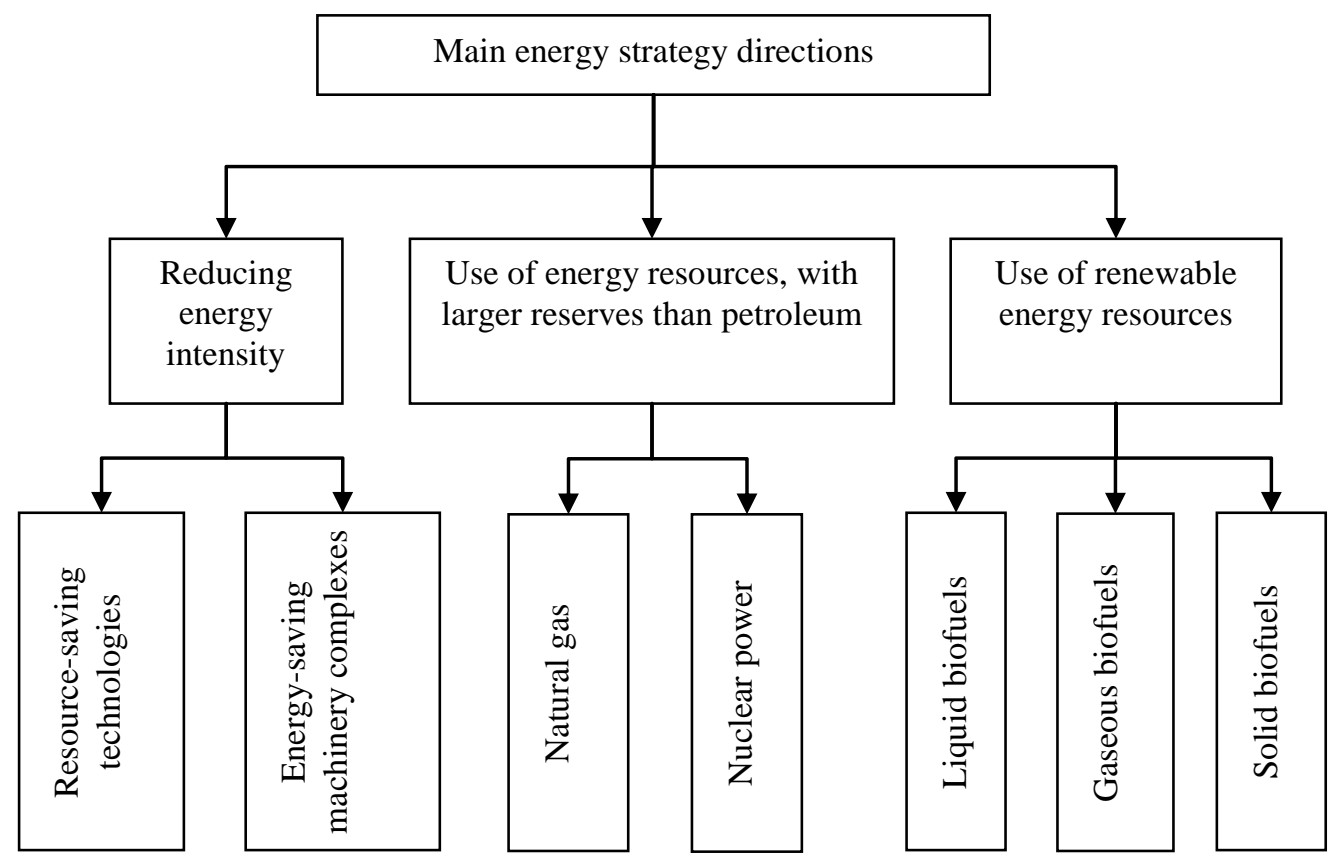

Figure 1. Main energy strategy directions in power engineering

A significant number of countries are increasing biogas production (ePURE, 2014; Alberici and Toop, 2013). Thus, in China, biogas production has reached 15 billion $\mathrm{m}^{3}$ per year. This equals about 7,5 million tons of oil equivalent. Futhermore, in the EU, biogas production exceeds 13 million tonnes of oil equivalent (EBA, 2013).

Moreover, biogas meets recent environmental requirements. In accordance with the requirements of the Directive 2009/28/EC, reduction of greenhouse gas emissions in the implementation of renewable energy technologies should be at least 35\% compared to fossil fuels use. Biogas use reduces greenhouse gas emissions by $56-86 \%$, depending on 
the substrate and way of its utilization. This renewable gaseous fuel meets the requirements of the second generation biofuels (Geletukha at al., 2014). Thus, biogas production and use can be an attractive investment. Its use allows both to meet the requirements of the post-industrial society and make a significant contribution to the energy security.

All investment projects, including building of biogas plants, are subjected to risks. They are forced with uncertainty. It is a result of a lack of firm data concerning conditions and parameters of investment project implementation. The administration should focus on making decisions to achieve maximum profitability in the condition of uncertainty. Therefore, it is necessary to assess the impact of negative external factors on effectiveness of an investment project (Pikler, 2014).

Evaluation of investment projects is possible while applying different methods, such as the break-even analysis, sensitivity analysis, scenario method, theory of games, decision-making theory, etc. One of the simplest and most effective methods is sensitivity analysis. This analysis is a calculating procedure used to predict the impact of input data on output results of a project. This procedure is often used for investment decision-making related to investment project evaluation in conditions of uncertainty (Adler, 1987; Kalinichenko et al., 2016). However, the methodology of sensitivity analysis for investment projects of biogas producing is still not developed enough and needs to be investigated.

The aims of this study were to clarify the procedural technique for the sensitivity analysis of a biogas plant investment project, determine the degree of input values set influence on their cost-effectiveness and reveal the difference in results for the accepted criteria: $N P V$ and $P I$.

\section{Literature Review}

One of the challenges for the biofuel industry, including biogas plants, is the high level of uncertainty. These uncertainties complicate the assessment of investment decisions (Kim et al., 2011). The input variables are regarded as uncertain. These are the investment costs, discount rate, sale prices, sales volume, economic plant life, etc. The sales volume consists of electricity, heat, fertilizer, biomethane, by-product (carbon dioxide). They are every year changeable and dependent from the current market prices. Both the achievable sales volume and the selling price are uncertain (Blohm, 2006; Hoffmeister, 2008; Pikler, 2014).

The sensitivity analysis is suitable if there is no statistical data. It allows us to identify factors on which managers' attention should be focused during project implementation (Willem and Groenendaal, 1998; Borgonovo and Peccati, 2004). The purpose of the sensitivity analysis is selecting "critical" variables of the model which have the biggest influence on the criteria of an investment project and cause the most significant changes in these parameters.

The theoretical risk classification, assessment methods and risk management have been studied by a number of scientists. The analysis of these works shows that the risk is a complex, multifaceted phenomenon. There are different interpretations of the concept.

The studies were focused both on the general sensitivity analysis of investment projects and the risk in general (Milanović et al., 2010; Burja and Burja, 2009; Analti, 2003; Jovanovic, 1999). The sensitivity analysis is a mandatory attribute of the financial analysis of energy projects. 
Federica Cucchiella and Indiano de D'Amado have evaluated financial feasibility of biomethane plants and proposed a mathematical model. The Net Present Value and Discounted Payback Period are the indicators of the above. The sensitivity analysis on the critical variables was also conducted (Cucchiella and D'Amado, 2016). General aspects of the sensitivity analysis were studied by Mirela Iloiu and Diana Csiminga. In their research, viability of investment projects are based on the Internal Rate of Return $(I R R)$ and Net Present Value (NPV) criteria (Iloiu and Csiminga, 2009).

Despite the number of studies (Menind and Olt, 2009; Kossmann et al., 2009; Pingping, 2010; Arnórsso, 2011), the sensitivity analysis is still not very well understood and this reduces the quality of management decisions. The sensitivity analysis of biogas projects is used to facilitate decision making under uncertainty. This can provide an adequate insight into the possible problems for the decision maker (Mészáros, 2014).

Peter Jovanovic considered the Net Present Value, Internal Rate of Return and Payback Period as criteria of investment projects (Jovanovic, 1999). In the authors' previous study, only $N P V$ was accepted as a criterion (Gavrish and Perebijnos, 2015). The $N P V$ is an absolute criterion, which cannot give an unambiguous answer about a project's suitability. In our opinion, the Profitability Index $(P I)$ is a more appropriate criterion. That is why both $N P V$ and $P I$ criteria are used for this study.

\section{Research Methodology}

The methods used in this study include on-site data collection and literature review. The on-site data collection includes technical information about biogas plants accumulating, their efficiency, risk and uncertainty. The literature review helps to do a financial analysis.

First of all, we defined a set of criteria as a basis for the investment project evaluation. The assessment of an investment project is actually based on an estimation of future cash-flows. We also selected and identified a set of input key factors.

The resulting calculations are the values of individual criteria determining the values of certain input variables to determine the maximum (or minimum) values that certain variables can take if the investment project remains profitable. Finally, the results were analyzed and interpreted. It helps us to prevent or remove adverse impacts and make certain improvements.

\section{Mathematical Model Development}

In this study, the net present value and profitability index were chosen as criteria of the investment project. The $N P V$ and $P I$ have been selected as they are the main parameters for investors while making decisions.

The $N P V$ is a difference between the present value of cash inflows and present value of cash outflows. The profitability index is a ratio of payoff to investment of a suggested project. It allows to quantify an amount of value created per unit of investment. If the $P I$ is more than 1.2, a project is acceptable.

The sensitivity analysis procedure is as follows:

- identify all the variables used to calculate the output of economic analyses;

- carry out a qualitative analysis for an impact of the variables in order to select those having little or marginal elasticity;

- having chosen the significant variables, it is possible to evaluate their elasticity; 
- identify the critical variables, apply the chosen criterion.

In the investment project evaluation, there is a set of input values (income, costs, discount rate, value of investments, etc.) and a set of output ones (NPV and PI). Having used the input values, it is possible to determine certain individual output values (Fig. 2) (Stone, 1988).

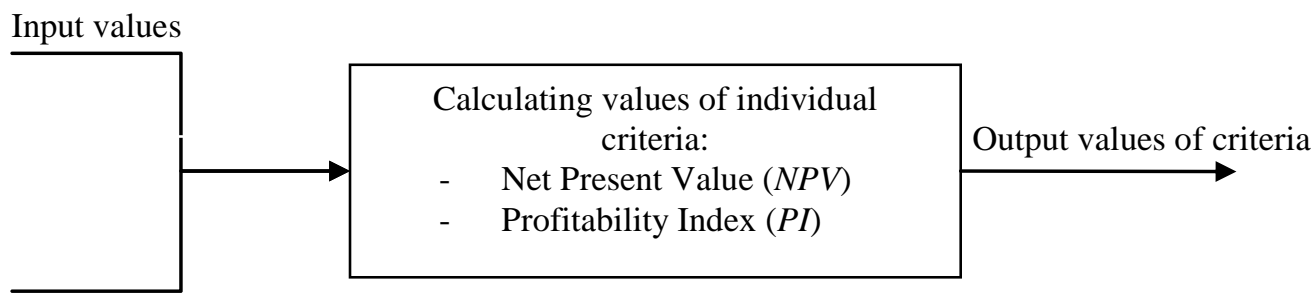

Figure 2. Calculation of individual criteria using input and output values

Let us analyze the critical points, i.e. determine the level of project-specific factors leading to the zero net present value. With respect to the biogas plant, the $N P V$ is defined by the following formula

$$
N P V=\sum_{i=1}^{n} \frac{G I_{i}-O C_{i}}{(1+d)^{i}}-\left(I_{0}+\sum_{j} \frac{I_{a j}}{(1+d)^{T_{j}}}\right),
$$

where $G I_{i}$ is a gross revenue from the biogas plant operation (use of electrical energy, thermal energy, biomethane as motor fuel, carbon dioxide, manure, etc.) in the $i^{\text {th }}$ time period, EUR; $O C_{i}$ is operating expenses in the ith period, EUR; $d$ is the discount rate; $n$ is the economic plant life, years; $I_{0}$ is the initial cost of the total investment, EUR; $I_{a j}$ is a the cost of the $j^{\text {th }}$ additional investments, EUR; $T_{j}$ is time of the $j^{\text {th }}$ additional investment, years.

While projects are planned to operate and be efficient for a time period of approximately 20 - 25 years, we assume that their plant life is 20 years (Gkamplia et al., 2012; Henning, 2011). But a depreciation period of some equipment (pumps, stirrers, heating system, combined heat and power generation, etc.) is shorter and is about $7-10$ years (Henning, 2011). So, additional investments are made to renovate some equipment with shorter lifetimes.

As for the profitability index, its value should not be less than 1.2

$$
P I=\frac{\sum_{i=1}^{n} \frac{G I_{i}-O C_{i}}{(1+d)^{i}}}{\left(I_{0}+\sum_{j} \frac{I_{a j}}{(1+d)^{T_{j}}}\right)} \geq 1.2
$$

Next, we will consider three ways of biogas utilization with:

- combined heat and power generation;

- motor fuel replacement; 
- motor fuel substitution and carbon dioxide use (resulting in biogas upgrading).

We propose to study an impact of the following major risk factors:

- the initial investment value;

- the additional investments value;

- the substrate cost;

- the biogas plant load factor;

- the discount rate;

- the actual biogas plant life;

- biogas plant operating expenses;

- revenue from electric power sale;

- revenue from heat sale;

- revenue from biogas (biomethane) sale (as motor fuel);

- revenue from carbon dioxide (by-product of biogas upgrading) sale.

The factors having a low variation are the most risky elements of the investment project. The relative deviation of each factor is determined as follows:

$$
\Delta F=\frac{F_{c r}-F_{o}}{F_{o}} \cdot 100 \%
$$

where $F_{o}$ is the influence factor value established according to the initial prognosis; $F_{c r}$ is the critical influence factor value.

To determine the degree of influence of each factor on the net present value, we should to determine the elasticity coefficient. Therefore, we use the following formulas:

$$
E_{N P V / F}=\frac{d N P V / N P V}{d F / F}
$$

or

$$
E_{P I / F}=\frac{d P I / P I}{d F / F}
$$

These expressions determine the elasticity at a particular point. In many cases (including dependence of the linear model), elasticity is different at various points. Thus, it is advisable to calculate the average value of the elasticity coefficient as a ratio of percentage changes in $N P V, P I$ and $F$

$$
E_{N P V / F}=\frac{\Delta N P V / \overline{N P V}}{\Delta F / \bar{F}}
$$

or

$$
E_{N P V / F}=\frac{\Delta P I / \overline{P I}}{\Delta F / \bar{F}}
$$

Having taken into account that (for $N P V$ ) 


$$
\begin{aligned}
& \Delta N P V=N P V\left(F_{c r}\right)-N P V\left(F_{o}\right), \\
& \Delta F=F_{o}-F_{c r}, \\
& \bar{F}=0,5 \cdot\left(F_{o}+F_{c r}\right), \\
& \overline{N P V}=0,5 \cdot\left(N P V\left(F_{o}\right)+N P V\left(F_{c r}\right)\right),
\end{aligned}
$$

we get the final expression for the elasticity coefficient (for $N P V$ )

$$
E_{N P V / F}=\frac{\left(N P V\left(F_{c r}\right)-N P V\left(F_{o}\right)\right) /\left(N P V\left(F_{o}\right)+N P V\left(F_{c r}\right)\right)}{\left(F_{c r}-F_{o}\right) /\left(F_{o}+F_{c r}\right)}
$$

A positive value of the elasticity coefficient indicates the coincidence of trends of both factors and the net present value, and a negative one - that the directions of the changes of a factor and $N P V$ have different signs. In equation (1) at the critical point $N P V\left(F_{c r}\right)=0$. If $N P V\left(F_{c r}\right)=0$, then the elasticity factor is

$$
E_{N P V / F}=\frac{\left(0-N P V\left(F_{o}\right)\right) /\left(N P V\left(F_{o}\right)+0\right)}{\left(F_{c r}-F_{o}\right) /\left(F_{o}+F_{c r}\right)}=-\frac{F_{o}+F_{c r}}{F_{c r}-F_{o}}
$$

Similarly, we obtain the expression for the profitability index

$$
E_{P I / F}=\frac{\left(P I\left(F_{c r}\right)-P I\left(F_{o}\right)\right) /\left(P I\left(F_{o}\right)+P I\left(F_{c r}\right)\right)}{\left(F_{c r}-F_{o}\right) /\left(F_{o}+F_{c r}\right)}
$$

In equation (2) at the critical point $P I(F c r)=1.2$.

\section{Sensitivity Analysis Procedure}

Performing the sensitivity analysis procedure involves the study of changes in the indicator, considering the remaining constants. If we take into consideration that the additional capital investments are made once in a biogas plant lifetime, the equation (1) is simplified and takes the following form

$$
N P V=\sum_{i=1}^{n} \frac{G I_{i}-O C_{i}}{(1+d)^{i}}-\left(I_{0}+\frac{I_{a j}}{(1+d)^{T_{j}}}\right)
$$

If we assume that there is a regular cash flow, the annual return will be

$$
R_{0}=G I_{i}-O C_{i}=\text { const }
$$

So,

$$
N P V=\sum_{i=1}^{n} \frac{G I_{i}-O C_{i}}{(1+d)^{i}}-\left(I_{0}+\frac{I_{a j}}{(1+d)^{T_{j}}}\right)=R \cdot \sum_{i=1}^{n} \frac{1}{(1+d)^{i}}-\left(I_{0}+\frac{I_{a j}}{(1+d)^{T_{j}}}\right)
$$

Let us determine the critical point, i.e. the value of specific factors leading to zero net 
present value.

All the factors influencing the project effectiveness can be divided into two groups: the first group includes general ones (independent on technological features of the investment project) and the second group (dependent on technology). The values of the initial investment, additional capital investment, lifetime, discount rate belong to the first group. The values of the biogas plant load factor, revenue from energy resourses (biomethane, electric and heat power) and carbon dioxide sale belong to the second group.

The actual investment costs may deviate from the established ones according to the initial prognosis. They may be a result of tax legislation amendments, for example. The critical value of the initial investment is

$$
I_{c r}=R_{0} \cdot \sum_{i=1}^{n} \frac{1}{(1+d)^{i}}-\frac{I_{a j}}{(1+d)^{T_{j}}}
$$

where $R_{0}$ is the annual return according to the initial prognosis.

Such substitution can be made in case of constant difference in the gross income and operation expenditure during the project lifetime.

The critical value of additional investment is

$$
I_{a j c r}=(1+d)^{T_{j}} \cdot\left(R_{0} \cdot \sum_{i=1}^{n} \frac{1}{(1+d)^{i}}-I_{0}\right)
$$

The critical value of the annual return is

$$
R_{c r}=\frac{\left(I_{0}+\frac{I_{a j}}{(1+d)^{T_{j}}}\right)}{\sum_{i=1}^{n} \frac{1}{(1+d)^{i}}}
$$

The critical value of the project lifetime can be determined as the discounted payback period (provided it is shorter than the additional investment period). If we take into account that

$$
\sum_{i=1}^{n} \frac{1}{(1+d)^{i}}=\frac{1-(1+d)^{-n}}{d}
$$

the discounted payback period is equal to 


$$
T c r=D P P=-\frac{\ln \left(\begin{array}{c}
I_{0}+\frac{I_{a j}}{(1+d)^{T j}} \\
R_{0}
\end{array}\right)}{\ln (1+d)}
$$

The critical value of the discount rate is found from the equation

$$
0=\sum_{i=1}^{n} \frac{R_{0}}{\left(1+d_{c r}\right)^{i}}-\left(I_{0}+\frac{I_{a j}}{\left(1+d_{c r}\right)^{T_{j}}}\right)
$$

where $d_{c r}$ is the critical value of the discount rate.

The root of the equation (19) is found numerically. In fact, the critical value of the discount rate is equal to the internal rate of return, i.e. $d_{c r}=I R R$.

Let us consider the factors that are directly determined by the parameters of the biogas plant and its products. A gross income from the biogas plant operation and all related costs are determined as follows. Based on this, we consider the impact of the following factors on the project effectiveness: the substrate cost, operating expenses, heat and electricity use, biomethane use to replace conventional motor fuel (gasoline or diesel), carbon dioxide use.

The substrate cost is equal to

$$
S C=M_{s} \cdot S_{p r}
$$

where $M_{s}$ is the annual consumption of the substrate, ton; $S_{p r}$ is the substrate price (production cost), EUR/t.

The critical value of the substrate price (production cost) can be found from the following formula

$$
R_{0}-R_{c r}=M s \cdot\left(S_{p r_{0}}+\left(S_{p r_{c r}}-S_{p r_{0}}\right)\right)
$$

where $S_{p r_{0}}$ is the substrate price (production cost) in the base case, EUR/t; $S_{p r_{c r}}$ is the critical value of the substrate price (production cost), EUR/t.

So, the critical value of the substrate price (production cost) is

$$
S_{p r_{c r}}=\frac{R_{0}-R_{c r}}{M_{s}}=\frac{R_{0}-\frac{\left(I_{0}+\frac{I_{a j}}{(1+d)^{T_{j}}}\right)}{\sum_{i=1}^{n} \frac{1}{(1+a)^{i}}}}{M_{s}}
$$

The critical value of operating expenses is 


$$
O C_{c r}=G I-\frac{\left(I_{0}+\frac{I_{a j}}{(1+d)^{T_{j}}}\right)}{\sum_{i=1}^{n} \frac{1}{(1+d)^{i}}}
$$

Let us consider three possible options of the biogas plant project. A company (a founder of the biogas plant project) may consume both heat and electric energy. Three options of biogas utilization have been considered:

- the company's energy requirements are covered with heat and electric energy produced by biogas plants;

- upgraded biogas (biomethane) is used as motor fuel (instead of petroleum fuels), carbon dioxide (a by-product of upgrading) is not used;

- both upgraded biogas (biomethane) and carbon dioxide are utilized or sold at the market price.

Biomethane and carbon dioxide are primary meant to be sold externally.

The gross income for the first option is determined as follows:

$$
G I=W_{e} \cdot E_{p r}+Q_{e} \cdot H_{p r}+M_{m} \cdot M_{p r}
$$

where $W_{e}$ is electric energy production and use, $\mathrm{kWh} ; Q_{e}$ is heat energy production and use, $\mathrm{kWh} ; E_{p r}$ is the electric energy price, EUR/kWh; $H_{p r}$ is the heat price, EUR/kWh; $M_{m}$ is the annual manure production, $\mathrm{t} ; M_{p r}$ is the manure price, EUR/t.

So, the critical values of the electricity and heat consumption will be

$$
W_{e r r}=W_{e}-\frac{R_{o}-R_{c r}}{E_{p r}}
$$

and

$$
Q_{e c r}=Q_{e}-\frac{R_{o}-R_{c r}}{H_{p r}}
$$

The critical value of the manure utilization volume is

$$
M m_{c r}=M m_{o}-\frac{R_{o}-R_{c r}}{M_{p r}}
$$

The equation for determining the gross income in the second option is

$$
G I=V_{b} \cdot \frac{Q_{b}}{Q_{f}} \cdot F_{p r}+M s \cdot S_{p r}
$$

where $F_{p r}$ is the motor fuel price, EUR/liter; $V_{b}$ is annual biogas production according to the initial prognosis, $\mathrm{m}^{3} ; Q_{b}$ is lower heat values of biogas, $\mathrm{MJ} / \mathrm{m}^{3} ; Q_{f}$ is lower heat values of motor fuel, $\mathrm{MJ} / \mathrm{kg}$. 
The critical value of biogas volume (in the form of biomethane) to substitute petroleum motor fuels is

$$
V_{b_{c r}}=V_{b 0}-\frac{R_{0}-R_{c r}}{F_{p r}} \cdot \frac{Q_{f}}{Q_{b}}
$$

The equation to determine the gross income in the third option is

$$
G I=V_{b} \cdot \frac{Q_{b}}{Q_{f}} \cdot F_{p r}+0,01 \cdot \xi \cdot V_{b} \cdot C D_{p r}+M_{m} \cdot M_{p r}
$$

where $V_{b 0}$ is annual production of biogas according to the initial prognosis, $\mathrm{m}^{3} ; \xi$ is carbon dioxide content in biogas, \%; $C D_{p r}$ is the carbon dioxide price, EUR/l.

The critical value of biogas volume (in the form of biomethane) to substitute petroleum motor fuels is determined by the formula (30), and the volume of carbon dioxide sale is

$$
V_{c d_{c r}}=0,01 \cdot \xi \cdot V b_{c r}=0,01 \cdot \xi \cdot V_{b 0}-\frac{R_{0}-R_{c r}}{C D_{p r}}
$$

If the maximum possible change of a factor does not result in reduction of the net present value to zero, the critical value of the net present value is

$$
N P V^{*}=N P V\left(F^{*}\right)
$$

where $F^{*}$ is the maximum possible value of a factor.

Let us consider the determining of critical points if profitability index is used as a criterion of an investment project. At the same time, we are going to take into account the fact that the profitability index values should be at least 1.2.

The critical value of the initial investment can be found from the equation of the profitability index

$$
P I^{*}=1,2=\frac{\sum_{i=1}^{n} \frac{R_{0}}{(1+d)^{i}}}{\left(I_{0}+\frac{I_{a j}}{\left(1+d_{c r}\right)^{T_{j}}}\right)}
$$

So,

$$
I_{c r}=\frac{\sum_{i=1}^{n} \frac{R_{0}}{(1+d)^{i}}}{P I^{*}}-\frac{I_{a j}}{\left(1+d_{c r}\right)^{T_{j}}}
$$

The critical value of the additional investment is 


$$
I_{a j c r}=\left(1+d_{c r}\right)^{T_{j}} \cdot\left(\frac{\sum_{i=1}^{n} \frac{R_{0}}{(1+d)^{i}}}{P I^{*}}-I o\right)
$$

The critical value of the annual return is

$$
R_{c r}=P I^{*} \cdot \frac{\left(I o+\frac{I_{a j}}{\left(1+d_{c r}\right)^{T_{j}}}\right)}{\sum_{i=1}^{n} \frac{1}{(1+d)^{i}}}
$$

The critical value of the economic plant life is to equal to the Discounted Payback Period $(D P P)$

$$
T_{c r}=D P P=-\frac{\ln \left(1-P I^{*} \cdot d \cdot \frac{I_{0}+\frac{I_{a j}}{(1+d)^{T j}}}{R_{0}}\right)}{\ln (1+d)}
$$

\section{Example of Sensitivity Analysis}

In order to exemplify the sensitivity analysis, the below biogas plant project is used. The annual capacity of biogas plant is equal to 599,1 thousand $\mathrm{m}^{3}$. The initial data for

\begin{tabular}{|c|c|c|c|c|c|}
\hline \multirow{2}{*}{ № } & \multirow{2}{*}{ Parameters } & \multirow{2}{*}{ Unit } & \multicolumn{3}{|c|}{ Options } \\
\hline & & & 1 & 2 & 3 \\
\hline 1 & Initial investment & $\begin{array}{l}\text { thousand } \\
\text { EUR }\end{array}$ & 765.22 & 884.78 & 913.48 \\
\hline 2 & Additional investment & $\begin{array}{c}\text { thousand } \\
\text { EUR }\end{array}$ & 191.30 & 310.87 & 339.57 \\
\hline 3 & Period of additional investment & year & \multicolumn{3}{|c|}{11.00} \\
\hline 4 & Annual biogas production & thousand $\mathrm{m}^{3}$ & \multicolumn{3}{|c|}{590.21} \\
\hline 5 & Lifetime of project & year & \multicolumn{3}{|c|}{20.00} \\
\hline 6 & Discount rate & & \multicolumn{3}{|c|}{7.50} \\
\hline 7 & $\begin{array}{l}\text { Annual consumption of } \\
\text { electricity by a biogas plant }\end{array}$ & $\begin{array}{l}\text { thousand } \\
\mathrm{kWh}\end{array}$ & \multicolumn{3}{|c|}{92.97} \\
\hline 8 & $\begin{array}{l}\text { Annual consumption of thermal } \\
\text { energy by a biogas plant }\end{array}$ & $\begin{array}{l}\text { thousand } \\
\mathrm{kWh}\end{array}$ & \multicolumn{3}{|c|}{449.36} \\
\hline 9 & Annual use of biogas to & thousand $\mathrm{m}^{3}$ & 0.00 & 282.73 & 282.73 \\
\hline
\end{tabular}
different variants is listed in Table 1 .

Table 1. Initial data for biogas plant project options 


\begin{tabular}{|c|c|c|c|c|c|}
\hline 10 & $\begin{array}{l}\text { substitute diesel fuel } \\
\text { Annual carbon dioxide } \\
\text { production }\end{array}$ & thousand $\mathrm{m}^{3}$ & 0.00 & 0.00 & 171.75 \\
\hline 11 & $\begin{array}{l}\text { Company's annual electrical } \\
\text { power consumption }\end{array}$ & $\begin{array}{l}\text { thousand } \\
\mathrm{kWh}\end{array}$ & 1146.96 & 0.00 & 0.00 \\
\hline 12 & $\begin{array}{l}\text { Company's annual thermal } \\
\text { energy consumption }\end{array}$ & $\begin{array}{l}\text { thousand } \\
\mathrm{kWh}\end{array}$ & 1029.86 & 0.00 & 0.00 \\
\hline
\end{tabular}

To assess financial risks, we will use the above factors. The resulting calculations are demonstrated in Table 2.

Table 2. Project sensitivity analysis

\begin{tabular}{|c|c|c|c|c|c|c|c|}
\hline \multirow[b]{3}{*}{ № } & \multirow[b]{3}{*}{ Parameters } & \multicolumn{6}{|c|}{ Relative deviation } \\
\hline & & \multicolumn{2}{|c|}{ Option 1} & \multicolumn{2}{|c|}{ Option 2} & \multicolumn{2}{|c|}{ Option 3} \\
\hline & & 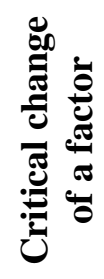 & 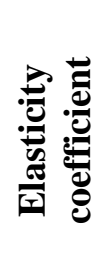 & 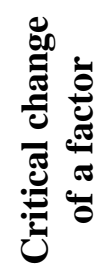 & 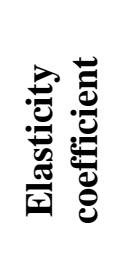 & 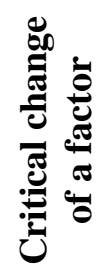 & 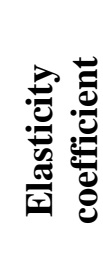 \\
\hline 1 & Initial investment & 0.61 & -4.30 & 0.36 & -6.55 & 1.58 & -2.26 \\
\hline 2 & Additional investment & 5.37 & -1.37 & 2.27 & -1.88 & 9.44 & -1.21 \\
\hline 3 & Plant's economic life & -0.59 & 2.37 & -0.52 & 2.88 & -0.77 & 1.58 \\
\hline 4 & Discount rate & 1.13 & -2.77 & 0.84 & -3.39 & 2.57 & -1.78 \\
\hline 5 & $\begin{array}{l}\text { Biogas plant-load } \\
\text { factor }\end{array}$ & -0.35 & 4.67 & -0.24 & 7.43 & -0.58 & 2.47 \\
\hline 6 & Substrate cost value & 1.45 & -2.38 & 1.00 & -3.00 & 4.53 & -1.44 \\
\hline 7 & Operating expenses & 0.76 & -3.64 & 0.15 & -14.62 & 0.58 & -4.45 \\
\hline 8 & Electric energy use & -0.41 & 3.91 & - & - & - & - \\
\hline 9 & Thermal energy use & -0.99 & 1.03 & - & - & - & - \\
\hline 10 & Manure sale* & -1.00 & 0.90 & -0.73 & 1.76 & -1.00 & 0.54 \\
\hline 11 & Diesel fuel substitute & - & - & -0.12 & 15.51 & -0.55 & 2.64 \\
\hline 12 & Carbon dioxide sale & - & - & - & - & -0.94 & 1.13 \\
\hline
\end{tabular}

* Zero scope of manure use does not lead to a decrease in the net present value to zero in the first and third options.

The obtained data shows the main risk factors for the project:

- the first option - biogas is utilized to generate electric or/and heat power;

- the second and third options --biogas is used to substitute diesel fuel.

The projects' options prove to be stable to the value of an additional investment and substrate cost value. Use of the $P I$ as a criterion for an investment project gives lower values of the input critical variables (Table 3 ). 
Table 3. Comprehensive assessment of the project sensitivity

\begin{tabular}{|c|c|c|c|c|c|c|c|}
\hline \multirow[b]{2}{*}{ № } & \multirow[b]{2}{*}{ Parameters } & \multicolumn{2}{|c|}{ Option 1} & \multicolumn{2}{|c|}{ Option 2} & \multicolumn{2}{|c|}{ Option 3} \\
\hline & & 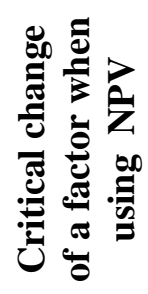 & 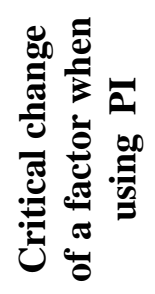 & 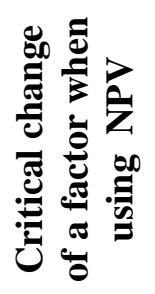 & 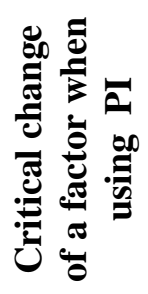 & 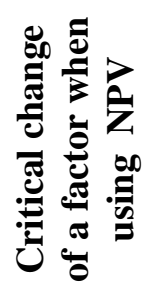 & 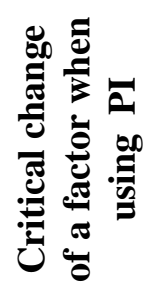 \\
\hline 1 & $\begin{array}{l}\text { Initial investment } \\
\text { value }\end{array}$ & 0.61 & 0.32 & 0.36 & 0.11 & 1.58 & 1.12 \\
\hline 2 & $\begin{array}{c}\text { Additional } \\
\text { investment value }\end{array}$ & 5.37 & 2.86 & 2.27 & 0.67 & 9.44 & 6.68 \\
\hline 3 & Project lifetime & -0.59 & -0.38 & -0.52 & -0.17 & -0.77 & -0.66 \\
\hline 4 & $\begin{array}{l}\text { Biogas plant load } \\
\text { factor }\end{array}$ & -0.35 & -0.22 & -0.24 & -0.08 & -0.58 & -0.49 \\
\hline
\end{tabular}

The sensitivity analysis of the project was carried out graphically. It is proposed to improve the classic method by introducing a line of the minimum allowable value project performance criteria $(N P V=0$ or $P I=1.2)$. In percentage terms, the $N P V=-$ $100 \%$, while for the PI it is

$$
\delta P I=\frac{P I^{*}-P I}{P I} \cdot 100 \%
$$

Fig. 3 shows that 20\% decrease of return and $30 \%$ increase of investment cause critical reduction of $P I$. In the second option, $10 \%$ deviation of investment or return makes the project unprofitable (Fig. 4). The third option proves to be the most stable one (Fig. 5). The sensitivity analysis shows that the $N P V$ and $P I$ approximately respond to changes in the biogas plant capacity.
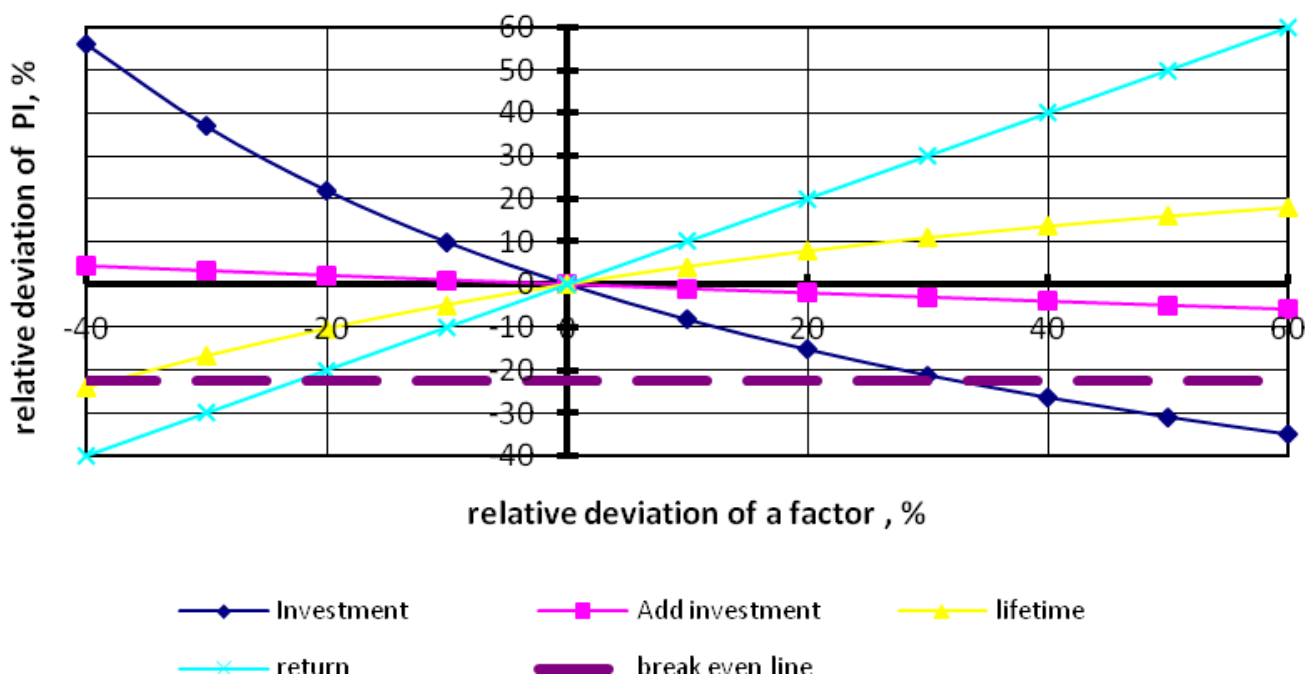

Figure 3. Sensitivity analysis of the first option 


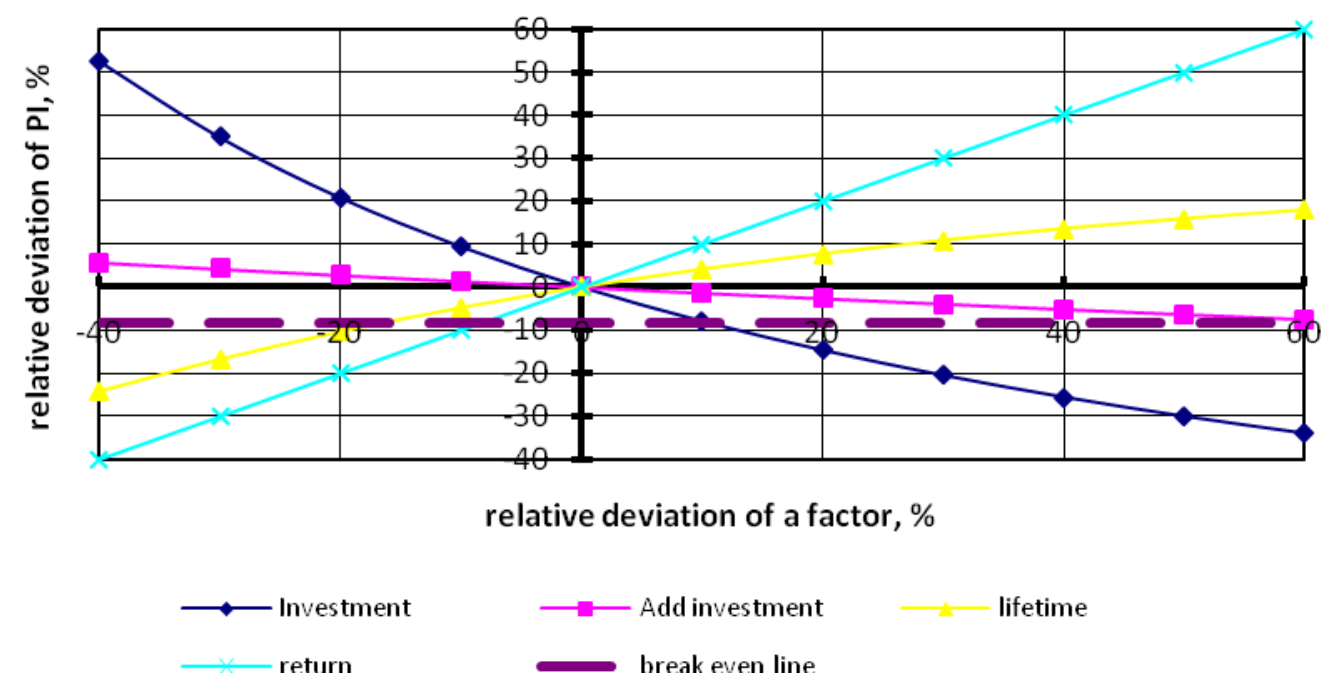

Figure 4. Sensitivity analysis of the second option

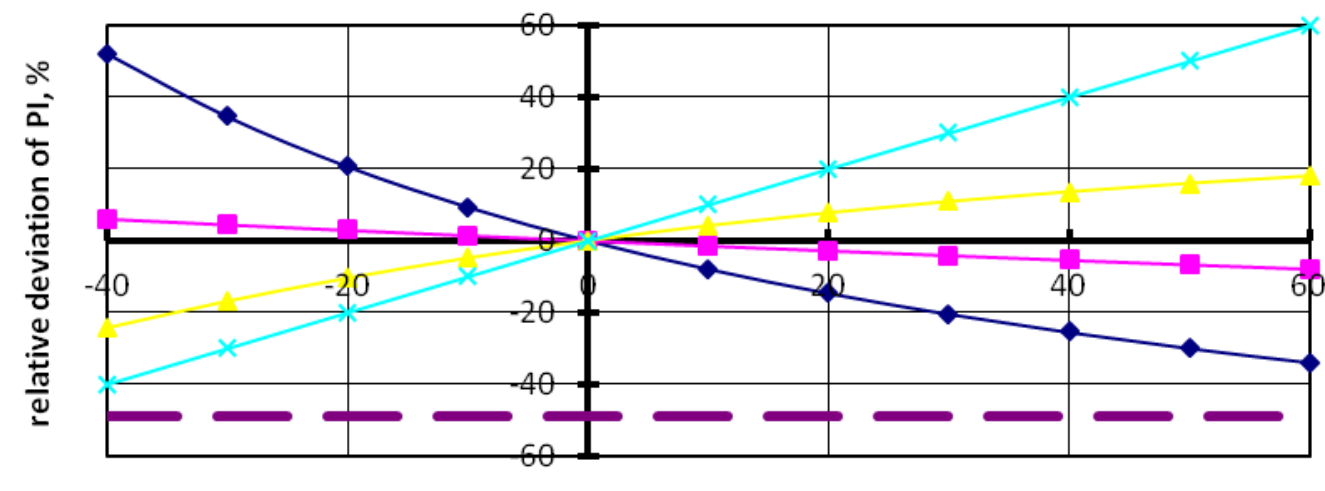

relative deviation of a factor, $\%$

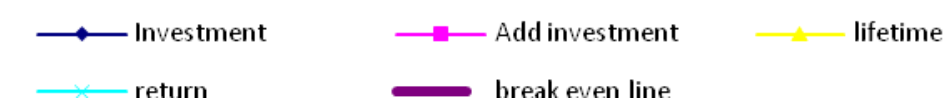

Figure 5. Sensitivity analysis of the third option

\section{Conclusions}

The profitability index is proposed to be used as a criterion of an investment project for the sensitivity analysis procedure. It can guarantee profitability of an investment project at the critical points. The economic and mathematical model for sensitivity analysis of an investment project of biogas plant has been developed. It takes into account the main input factors having influence on a project criterion.

According to the calculations for the biogas plant projects, the most risky option is to use biogas as vehicle fuel and not to use its by-product (carbon dioxide). The most sustainable project is using both biomethane (as vehicle fuel) and carbon dioxide for sale. This study has revealed that biogas plant progects are more sensitive to biogas 
plant load factor, and less sensitive to the additional investment and substrate cost.

For further research, we suggest taking into account the scenario method to study probability of external factors. The sensitivity analysis methodology can be improved. The price ratio of biomethane and petroleum fuels should be subject to future study. Moreover, location and capacity have a high level of uncertainty.

\section{REFERENCES}

[1] Adler, H. A. (1987): Economic Appraisal of Transport Projects. - The Johns Hopkins University Press, Baltimore. http://documents.worldbank.org/ curated/en/383421468767365929/pdf/multi-page.pdf

[2] Alberici, S., Toop, G. (2013): UK biofuel industry overview. - ECOFYS UK, London. https://www.gov.uk/government/uploads/system/uploads/attachment_data/file/266090/ec ofys-uk-biofuel-industry-overview-v1.5.pdf

[3] Analti, A. (2003): How Sensitive Is Investmentto Cash FlowWhen Financing Is Frictionless? - The Journal of Finance LVIII(2): 707-721. http://apps.olin.wustl.edu/faculty/liuh/Research/Brown_Bag_Alti.pdf

[4] Arnórsso, H. (2011): A Feasibility Study of Using Biomethane As an Alternative Fuel For Taxis in the Reykjavik Capital Area. - University of Iceland \& University of Akureyri. Akureyri. http://skemman.is/stream/get/1946/7686/20278/1/MSc_RES_Hannes _Arnorsson_Final_Feb_2011.pdf

[5] Blohm, H., Lüder, K., Schäfer, C. (2006): Investition - Schwachstellenanalyse des Investitionsbereichs und Investitionsrechnung. 9. Auflage. - München.

[6] Borgonovo, E., Peccati, L. (2004): Sensitivity analysis in investment project evaluation. International Journal of Production Economics 90: 17-25. DOI: 10.1016/S09255273(03)00213-5

[7] Brower, K. P., Davison, B. H., Ragauskas, A. J., Templer, R. et al. (2006): Measuring the Efficiency of Biomass Energy. - Science 312 (5781): 1744-1745. DOI: 10.1126/science.312.5781.1744

[8] Burja, C. A., Burja, V. (2009): The Risk Analysis for Investments Projects Decision. Annales Universitatis Apulensis. Series Oeconomica 11(1): 98-105. http://www.oeconomica.uab.ro/upload/lucrari/1120091/09.pdf

[9] Cucchiella, F., D'Amado, I. (2016): Technical and economical analysis of biomethane: A focus on the role of subsidies. - Energy Conversion and Management 119: 338-351. DOI: 10.1016/j.enconman.2016.04.058

[10] EBA (European Biogas Association), (2013): Biogas production statistics for Europe growth continues. - http://european-biogas.eu/2013/12/20/eba-presents-latest-biogasproduction-statistics-europe-growth-continuous/.

[11] ePURE (2014): Renewable ethanol: driving jobs, growth and innovation throughout Europe. State of the Industry Report. - ePure, Brussels. http://epure.org/media/1137/stateof-the-industry-report-2014.pdf

[12] Gavrish, V. I., Perebijnos, V. I. (2015): Justification of investment projects of biogas systems by the sensitivity analysis. - Modern Management Technology 6(54). http://sovman.ru/en/article/5403/

[13] Geletukha, G., Zheliezna, T., Drozdova, O. (2014): UABio Nr 8. Energy and environmental analysis of bioenergy technology.

http://uabio.org/img/files/docs/position-paper-uabio-8-ua.pdf.

[14] Gkamplia, V., Kazantzi, V., Blanas, N., Aspridis, G. (2012): Economic Evaluation of Strategic Biogas Investment Options - Case Study in the Region of Larisa. - OralMIBES 141: 141-159. http://mibes.teilar.gr/proceedings/2012/oral/Gkamplia-KalatziBlanas-Aspridis.pdf 
[15] Henning, H. (2011): Guideline for financing agricultural biogas projects - Training material for biogas investors D.3.7, WP 3. - IEE Project 'BiogasIN'. http://www.biogasin.org/files/pdf/WP3/D.3.5_IWES_EN.pdf

[16] Hoffmeister, W. (2008): Investitionsrechnung und Nutzwertanalyse - Eine entscheidungsorientierte Darstellung mit vielen Beispielen und Übungen. 2. Auflage. Berlin.

[17] Iloiu, M., Csiminga, D. (2009): Project risk evaluation methods - sensitivity analysis. Annals of the University of Petroşani, Economics 9(2): 33-38. http://upet.ro/annals/economics/pdf/2009/20090205.pdf

[18] Jovanovic, P. (1999): Application of sensitivity analysis in investment project evaluation under uncertainty and risk. - International Journal of Project Management 17(4): 217222. DOI: $10.1016 / \mathrm{S} 0263-7863(98) 00035-0$

[19] Kalinichenko, A., Havrysh, V., Perebyynis, V. (2016): Evaluation of biogas production and usage potential. - Ecological chemistry and engineering S. 23(3): 387-400. DOI: 10.1515/eces-2016-0027

[20] Kim, J., Realff, M. J., Lee, J. H. (2011): Optimal design and global sensitivity analysis of biomass supply chain networks for biofuels under uncertainty. - Computers and Chemical Engineering 35(9): 1738-1751. DOI: 10.1016/j.compchemeng.2011.02.008

[21] Kossmann, W., Pönitz, U., Habermehl, S., Hoerz, T. et al. (2009): Biogas Digest. Vol. III. Biogas - Costs and Benefits and Biogas - Programme Implementation. - Information and Advisory Service on Appropriate Technology. http://www.pseau.org/outils/biblio/resume.php?d=3273

[22] LSB (Leaders of Sustainable Biofuels) (2013): Manifesto. http://www.sustainablebiofuelsleaders.com/img/Manifesto.pdf

[23] Menind, A., Olt, J. (2009): Biogas plant investment analysis, cost benefit and main factors. $\quad-$ Engineering and rural development 28: 339-343. http://tf.llu.lv/conference/proceedings2009/Papers/60_Andres_Menind.pdf

[24] Milanović, D. L. J., Milanović, D. D., Misita, M. (2010): The Evaluation of Risky Investment Projects. $\quad-\quad$ FME Transactions 38: 103-106. http://www.mas.bg.ac.rs/_media/istrazivanje/fme/vol38/2/07_mmisita.pdf

[25] Mészáros, A., Zbojovský, J., Kurimský, P. (2014): Economic evaluation of biogas plant. - Intensive Programme 2014: Perspectives for the development of low-power systems using biomass: 154-159. https://otik.uk.zcu.cz/bitstream/11025/16496/1/Meszaros.pdf

[26] Patyka, V., Buletsa, N., Pasichnyk L. et al. (2016): Specifics of pesticides effects on the phytopathogenic bacteria. - Ecological chemistry and engineering S. 23(2): 312-331. DOI: 10.1515/eces-2016-0022

[27] Pikler, B. V. (2014) Sustainable investment decision making for Biogas plants in Hungary and the utility cost reduction measure. - In: Voszka, E. and Kiss, G. D. (eds. ) Crisis Management and the Changing Role of the State. Szeged: University of Szeged Doctoral School in Economics: 157-170. http://www.eco.uszeged.hu/english/research/scientific-publications/crisis-management-and-the-changingrole-of-the-state

[28] Pingping, N. (2010): Economic and Ecological Aspects of Biogas Scene in China. Technische Unicersität München Lehrstuhl für Wirtschaftslehre des Landbaues. https://mediatum.ub.tum.de/doc/982173/982173.pdf

[29] Stern, N. (2007): Stern Review: The Economics of Climate Change. http://mudancasclimaticas.cptec.inpe.br/ rmclima/pdfs/destaques/sternreview_report_co mplete.pdf

[30] Stone, R. (1988): Management of Engineering Projects. - Macmillan Education, London. http://link.springer.com/chapter/10.1007\%2F978-1-349-19572-5_3

[31] Willem, J. H., Groenendaal, V. (1998): Estimating NPV variability for deterministic models. - European Journal of Operational Research 107: 202-213. DOI: 10.1016/S03772217(97)00138-0 